Tér és Társadalom 17. évf. 2003/3. 145-163. p.

Tér és Társadalom

XVII. évf. 2003 3: 145-197

\title{
VERSENYKÉPESSÉG
}

\section{A MAGYAR VÁROSHÁLÓZAT TAGOZÓDÁSA AZ INFOKOMMUNIKÁCIÓS INFRASTRUKTÚRA ALAPJÁN AZ EZREDFORDULÓN}

\author{
(The Hungarian Urban Network's Structure Based on the \\ Information and Communication Infrastructure \\ at the Turn of the Millennium)
}

\section{RECHNITZER JÁNOS - GROSZ ANDRÁS - CSIZMADIA ZOLTÁN}

Kulcsszavak:

városhálózat információs és kommunikációs technológiák Magyarország

Az elnúlt években tapasztalható megtorpanása, kisebb recessziója ellenére is az információs és kommunikációs technológiák (IKT) egyre inkább meghatározóvá válnak a globalizált világ gazdaságában, illetve a rendszerváltást követö gazdasági szerkezetváltásnak köszönhetōen már hazánk nemzetgazdaságában is. Az IKT hatását elsösorban a termelékenység javitásában, üj termékek és szolgáltatások megjelenésében, a fogyasztói szokások átalakulásában, új elosztási csatornák kialakulásában szokás megragadni, ugyanakkor az információs és kommunikációs technológiák eröteljes területi koncentrációjának köszönhetöen igen jelentôs hatással van a térszerkezet változására, különösen a városhálózat tagozódâsára. Hazánkban is megfigyelhetó az IKT szektor jelenléte, szerkezete tekintetében a hasonló sajátosságokat mutató városcsoportok kialakulása, mely folyamatot elsösorban a városok mérete, telepiulés hierarchiában betöltött funkciói, foldrajzi elhelyezkedése, valamint egyéb speciális jellemzôi határozzák meg.

\section{Bevezetés}

A magyar városhálózatban a politikai és gazdasági rendszerváltozás hatásai kimutathatók voltak. A korábbi kutatások arra irányultak, hogy miként volt képes fogadni ez a hálózat a gazdasági és társadalmi megújítás hordozóit (Rechnitzer 1993). Az elemzések megállapították, hogy a gazdasági és a közigazgatási funkciókat tömörítô, többségében regionális szerepkörrel rendelkezö centrumok tudták a legkisebb vesztességgel elviselni a rendszerváltozás következményeit. A tradicionális középvárosoknál egy hosszabb átmeneti szakasz kezdỏdött el, aminek a kimenetele a vizsgálat időszakában még kérdéses volt. Ugyanakkor a kisvárosokat lehetett az egyértelmü veszteseknek tekinteni a rendszerváltozás elsỏ szakaszában. Több vizsgálat (Nemes Nagy 1995; Beluszky 1999; Lengyel-Rechnitzer 2000) megerỏsítette azt, hogy nemcsak a városi szerepköröket megtestesítö intézmények jelenléte, hanem a centrumok fóldrajzi helyzete is befolyásolta az átmenet folyamatait.

A kilencvenes évtized végén megismételt vizsgálatok (Grosz-Rechnitzer 2000; Rechnitzer 2002) már egy jóval differenciáltabb városhálózatot mutattak be. A 
hálózat megosztottságában döntő szerepe volt az üzleti és gazdasági szolgáltatásoknak, valamint az elérhetöségnek, a közlekedési kapcsolatok alakulásának. A regionális szerepkörrel bíró centrumok helyzete stabilizálódott, kiemelkedtek az $u j j$ funkciókra specializálódó (idegenforgalom, a fövárosi agglomeráció) kis és középvárosok, valamint a tradicionális, azaz 20-30 évvel ezelött városi rangot nyert közép és kisvárosok helyzetüket javították (pl. térségi szervező szerepeiket bövítették, stabilizálták intézményeiket stb.) az évtized elejéhez képest. A periférikus helyzetü, valamint a kilencvenes években városi rangot nyert központok viszont nem tudtak még integrálódni a hálózatba, azoknál csupán a hagyományos városi funkciók regisztrálhatók, a megújítás képviselő eszközök és intézmények csak elvétve jelennek meg, s a hatásaik sem számottevök.

A magyar városhálózat jellemzőinek tudatos feltárásánál nem feledkezhettünk meg arról, hogy vizsgáljuk a hálózat fogadókészségét a legújabb és egyben a legdinamikusabban terjedö technológiák és az azokat megtestesítö ismeretek iránt. Az információs technikák látványos szétterülését tapasztaltuk a kilencvenes évek végi Magyarországon, mely folyamatban a városhálózat szerepe meghatározónak tekinthető. Kísérletet tettünk tehát többszintü elemzéssel arra, hogy értékeljük az infokommunikációs technikák fogadásának sajátosságát a magyar városok esetében (Döry-Grosz 2002). Ennek az elemzésnek az egyik metszetét mutatjuk be tanulmányunkban, éspedig magának a hálózatnak a megosztottságát, tagozódását e technikai, de mondhatjuk életmódbeli változásokat is megtestesítő eszközrendszer megjelenése és elterjedése révén.

\section{Az infokommunikációs vizsgálat során felhasznált mutatók}

Az elemzés alapját a 2001-ben városi jogállással rendelkezö 251 település alkotta. A vizsgálatból kihagytuk a fővárost, Budapestet, ugyanis annak kiugróan eltérő mutatói komoly torzuláshoz vezettek volna. Az eredményekben dominált volna a Budapest és a többi város közötti különbségek sajátossága, s így háttérbe szorult volna a városok között meglévő fejlettségbeli, infokommunikációs versenyképességben megmutatkozó eltérés.

A vizsgálatot két mutatórendszerrel is elvégeztük. Ezek közül az egyik elemzés egy komplexebb - összesen 32 különbözö változót magában foglaló - ismérvrendszeren alapul, míg a másik sokkal szükebb, kifejezetten csak az infokommunikációs technológiai (IKT) szektorral közvetlenül kapcsolatba hozható 12 indikátort foglalja magában. A komplex mutatórendszerben az IKT változók mellett - melyek az összes mutató közel felét jelentették - kisebb súllyal, de szükségesnek éreztük szerepeltetni az olyan legalapvetőbb városi fejlettségre utaló tényezöket, mint demográfia, jövedelmi helyzet, gazdasági mutatók, vagy a humán eröforráshoz kapcsolódó jellemzök, hiszen ezek a változók szoros kapcsolatban vannak az egyes városok infokommunikációs jellemzőivel. A település mérete (lakosságszáma), az ott élök jövedelmi helyzete keresleti oldalról gyakorol hatást a szektorra, míg a humán eröforrás legfontosabb jellemzői, valamint a gazdasági szféra általános mutatói kínálati 

Tér és Társadalom, 17. 2003. 3. 145-163. $p$.

oldalról határozhatják meg annak alakulását. A komplex és a szükebb IKT mutatórendszert - az egyes változókkal, az adatok vonatkozási dátumával, valamint azok forrásmegjelölésével - az 1-2. táblázat tartalmazza.

\section{TÁBLÁZAT}

A komplex mutatórendszerhez kapcsolódó indikátorok (Variables of the Complex Indicator System)

\begin{tabular}{|c|c|c|c|c|}
\hline Ssz. & Változó & $\begin{array}{l}\text { Egy } \\
\text { ség }\end{array}$ & Év & Forrás \\
\hline 1. & A település területe & ha & 1999 & KSH T-STAR \\
\hline 2. & A település állandó lakosságának száma & fö & 2000 & KSH T-STAR \\
\hline 3. & A vándorlási különbözet értéke & $\%$ & 2000 & KSH T-STAR \\
\hline 4. & Az öregségi index értéke & $\%$ & 2000 & KSH T-STAR \\
\hline 5. & A lakásállomány száma & $\mathrm{db}$ & 1999 & KSH T-STAR \\
\hline 6. & $\begin{array}{l}\text { Az év folyamán épített } 4 \text { szobás vagy annál nagyobb lakások } \\
\text { száma }\end{array}$ & $\mathrm{db}$ & 2000 & KSH T-STAR \\
\hline 7. & Az 1000 lakosra jutó személygépkocsik száma & $\mathrm{db}$ & 2000 & KSH T-STAR \\
\hline 8. & A személyi jövedelemadó (SZJA) alap teljes összege & $\mathrm{e} F t$ & 1999 & APEH SZJA \\
\hline 9. & A befizetett személyi jövedelemadó (SZJA) teljes összege & $\mathrm{e} \mathrm{Ft}$ & 1999 & APEH SZJA \\
\hline 10. & A regisztrált munkanélküliek aránya a 18-59 éves lakosságból & $\%$ & 2000 & KSH T-STAR \\
\hline 11. & $\begin{array}{l}\text { A tartósan (180 napon túl) munkanélküliek aránya a 18-59 éves } \\
\text { lakosságbói }\end{array}$ & $\%$ & 2000 & KSH T-STAR \\
\hline 12. & A dolgozó orvosok száma & fö & 1999 & KSH T-STAR \\
\hline 13. & Az általános iskolai tantermek száma & $\mathrm{db}$ & 1999 & KSH T-STAR \\
\hline 14. & A középiskolai tantermek száma & $\mathrm{db}$ & 1999 & KSH T-STAR \\
\hline 15. & Az összes középfokú intézmény száma & $\mathrm{db}$ & 1999 & KSH T-STAR \\
\hline 16. & Az informatikai képzést biztosító középfokú intézmények száma & $\mathrm{db}$ & 2001 & www.palya.hu \\
\hline 17. & Az informatikai képzést biztosító felsőfokú intézmények száma & $\mathrm{db}$ & 2001 & $\mathrm{OM}$ \\
\hline 18. & Az összes gazdasági szervezet száma & $\mathrm{db}$ & 2001 & KSH CKT \\
\hline 19. & Az 1000 lakosra jutó összes múködỏ vállalkozás száma & $\mathrm{db}$ & 2000 & KSH T-STAR \\
\hline 20. & Az 1000 lakosra jutó összes egyéni vállalkozás száma & $\mathrm{db}$ & 2000 & KSH T-STAR \\
\hline 21. & A feldolgozóipari IKT vállalkozások száma & $\mathrm{db}$ & 2001 & KSH CKT \\
\hline 22. & $\begin{array}{l}\text { A termékhez kapcsolódó IKT szolgáltatást nyújtó vállalkozások } \\
\text { száma }\end{array}$ & $\mathrm{db}$ & 2001 & KSH CKT \\
\hline 23. & $\begin{array}{l}\text { A termékhez nem kapcsolódó IKT szoigáltatást nyújtó vállaikozá- } \\
\text { sok száma }\end{array}$ & $\mathrm{db}$ & 2001 & KSH CKT \\
\hline 24. & A médiagazdaságban érintett vállalkozások száma & $\mathrm{db}$ & 2001 & KSH CKT \\
\hline 25. & Az internetes szolgáltatási formák száma & $\mathrm{db}$ & 2001 & BP HF \\
\hline 26. & Az internet szolgáltatást nyújtó vállalkozások száma & $\mathrm{db}$ & 2001 & BP HF \\
\hline 27. & A domain szerverek száma & $\mathrm{db}$ & 2001 & $\begin{array}{l}\text { MTA RKK } \\
\text { ATI }\end{array}$ \\
\hline 28. & Az 1000 lakosra jutó távbeszélő állomások száma & $\mathrm{db}$ & 2000 & KSH T-STAR \\
\hline 29. & Az üzleti vonalak aránya az összes távbeszélỏ vonalon belül & $\%$ & 2000 & KSH T-STAR \\
\hline 30. & Az egy mủködő válialkozásra jutó távbeszélő vonalak száma & $\mathrm{db}$ & 2000 & KSH T-STAR \\
\hline 31. & Az 1000 lakosra jutó Vodafone mobil elöfizetések száma & $\mathrm{db}$ & 2000 & Vodafon \\
\hline 32. & Az 1000 lakosra jutó Pannon GSM mobil elöfizetök száma & $\mathrm{db}$ & 2000 & Pannon GSM \\
\hline
\end{tabular}

Megjegyzés: CKT: Cég-Kód-Tár, BP HF: Budapesti Hírközlési Felügyelet, MTA RKK ATI: MTA Regionális Kutatások Központja Alföldi Tudományos Intézet

Forrás: Szerkesztette Grosz A.

A mutatórendszer összeállítása során, annak érdekében, hogy a faktoranalízis számára minél inkább alkalmas legyen az adatbázis, csak statikus, egy adott időpontra, időszakra vonatkozó tényezökkel dolgoztunk, és nem képeztünk időbeli változást mérő dinamikus mutatókat. Az egymással viszonylag szoros korrelációban álló mutatók közül (pl. összes vállalkozás száma, múködö vállalkozások száma, 
jogi személyiségü vállalkozások száma stb.) azokat választottuk ki, amelyek átfogóbb képet adnak a településszerkezetről. Az egyes adatok általában a legfrissebb, rendelkezésre álló KSH T-STAR adatbázisból származnak, így a 2000-es évre vonatkoznak. Mindazonáltal a 2000-es adatbázis hiányossága miatt egy-két esetben 1999-es adatokra kellett támaszkodnunk. A statisztikai adatbázisokban fel nem lelhetö, ezért saját adatgyüjtést igénylö mutatók esetében (pl. az infokommunikációs szektorhoz tartozó vállalkozások száma) lehetőség nyílt 2001-es információk számbavételére is (lásd 1-2. táblázat).

\section{TÁBLÁZAT}

Az IKT szektorra vonatkozó indikátorok

(Variables of the ICT Indicator System)

\begin{tabular}{|c|c|c|c|c|}
\hline & Változó & $\begin{array}{l}\text { Egy } \\
\text { ség }\end{array}$ & Év & Forrás \\
\hline 1. & Az informatikai képzést biztosító középfokú intézmények száma & $\mathrm{db}$ & 2001 & www palya.hu \\
\hline 2. & Az informatikai képzést biztosító felsőfokú intézmények száma & $\mathrm{db}$ & 2001 & OM \\
\hline 3. & A feldolgozóipari IKT vállalkozások száma & $\mathrm{db}$ & 2001 & KSH CKT \\
\hline 4. & $\begin{array}{l}\text { A termékhez kapcsolódó IKT szol gáltatást nyújtó vállalkozások } \\
\text { száma }\end{array}$ & $\mathrm{db}$ & 2001 & $\mathrm{KSH}$ CKT \\
\hline 5. & $\begin{array}{l}\text { A termékhez nem kapcsolódó IKT szolgáltatást nyújtó vállalkozá- } \\
\text { sok száma }\end{array}$ & $\mathrm{db}$ & 2001 & KSH CKT \\
\hline 6. & A médiagazdaságban érintett vállalkozások száma & $\mathrm{db}$ & 2001 & KSH CKT \\
\hline & Az internetes szolgáltatási formák száma & $\mathrm{db}$ & 2001 & BP HF \\
\hline & A domain szerverek száma & $\mathrm{db}$ & 2001 & $\begin{array}{l}\text { MTA RKK } \\
\text { ATI }\end{array}$ \\
\hline 9. & Az 1000 lakosra jutó távbeszélö állomások száma & $\mathrm{db}$ & 2000 & KSH T-STAR \\
\hline 10. & Az üzleti vonalak aránya az összes távbeszéló vonalon belül & $\%$ & 2000 & KSH T-STAR \\
\hline & Az 1000 lakosra jutó Vodafone mobil elöfizetések száma & $\mathrm{db}$ & 2000 & Vodafone \\
\hline & Az 1000 lakosra jutó Pannon GSM mobil elófizetök száma, & $\mathrm{db}$ & 2000 & Pannon GSM \\
\hline
\end{tabular}

Megjegyzés: KSH CKT: KSH Cég-Kód-Tár, BP HF: Budapesti Hírközlési Felügyelet, MTA RKK ATI: MTA Regionális Kutatások Központja Alföldi Tudományos Intézet

Forrás: Szerkesztette Grosz A.

A változóink egy része extenzív természetü (az esetek egyesítésével adataik öszszegződnek, pl. lakónépesség), és ezek mögött mindig egy volumen jellegü faktor is meghúzódik, másik része pedig intenziv, ill. arány típusú (az egyedek egyesítésekor súlyozott átlag képződik, pl. 1000 lakosra jutó személygépkocsi), melyek többnyire valamilyen dinamizmus jellegủ faktorhoz kapcsolódnak.

Az infokommunikációs technológiai szektor statisztikai mérésének hiányosságai miatt, az IKT mutatók egy-egy kivételtől eltekintve saját egyéni adatgyüjtésen alapulnak, és mindössze néhány található meg közvetlenül a Központi Statisztikai Hivatal adatbázisában. Ezen mutatókat, tartalmukat, forrásukat érdemes valamivel bövebben is bemutatni. A 17 mutató között az informatikai képzésre, az IKT vállalkozásokra, az internetes szolgáltatásokra és a telekommunikációs infrastruktúrára vonatkozó változók szerepelnek. A középfokú informatikai képzést biztosító középfokú intézmények számát ${ }^{1}$ az internetről, a www.palya.hu honlapról gyüjtöttük városonként össze, míg a felsőfokú intézmények száma ${ }^{2}$ az Oktatási Minisztérium Felsőoktatási Tájékoztatójából származik. A gazdasági szervezetek számát, valamint az IKT szektorhoz kapcsolódó vállalkozások számát a KSH Cég-Kód-Tár adatbázisából gyüjtöttük ki, minden egyes városra. Az IKT cégeket tovább csopor- 
tosítottuk a KSH hivatalos csoportosítása szerint ${ }^{3}$. Külön változóban szerepeltettük az infokommunikációs szektor egyik legfontosabb ágához, a médiagazdasághoz tartozó vállalkozások számát ${ }^{4}$. Az egyes településeken mủködő internetes szolgáltatást nyújtó vállalkozások, valamint az elérhető különbözö internetes szolgáltatási formák számát a Budapesti Hírközlési Felügyelet Hírközlési Szolgáltatások osztályának adatközlése alapján vettük be az adatbázisba. A városokban bejegyzett domain szerverek száma ugyancsak saját gyüjtésböl származik ${ }^{6}$. Végül a kommunikációs infrastruktúra felmérése során a hagyományos vezetékes telefonellátottság mellett fontosnak tartottuk a mobil szolgáltatók előfizetőinek számát is szerepeltetni az adatbázisban?

\section{A faktoranalizis alapján megfigyelhetö sajátosságok}

A városok kưlönböző típusainak meghatározásához, legalábbis az elözetes csoportok megállapításához tökéletesen alkalmas a két mutatórendszerből nyert faktorok (1. és 2. föfaktor) értékeinek kétdimenziós ábrázolása, hiszen a komplex mutatórendszerböl nyert elsỏ két faktor az eredeti 32 változót csaknem 65\%-ban képes magyarázni, míg az IKT mutatórendszer esetében a magyarázó érték meghaladja a 70\%-ot. Ezek alapján egyértelmúen elkülönülnek egymástól a későbbi klaszteranalízis eredményeként kapott infokommunikációs várostípusok. Mivel a két mutatórendszer alapján a várostípusok rendkívül hasonlóak, itt csak a komplex mutatórendszer eredményét ábrázoljuk ( 1 . ábra).

\section{1. ÁBRA}

A magyar városhálózat lehetséges típusai a komplex mutatórendszerböl

képzett 1. és 2. faktorértékek alapján

(Potential types of the Hungarian Urban Networks, on the basis

of the 1. and 2. Factor Values Resulting from the Complex Indicator System)

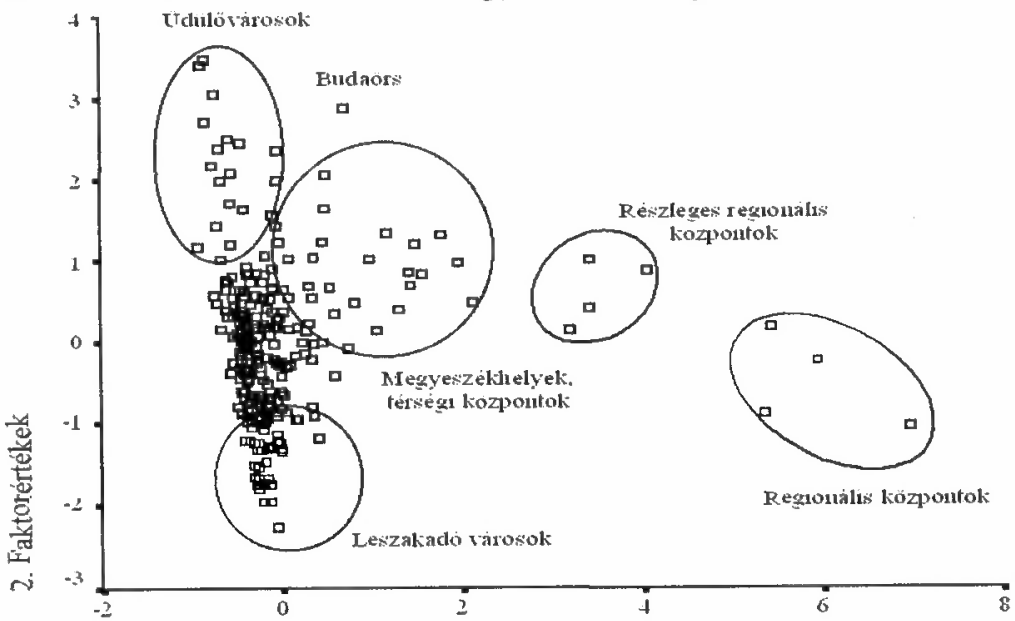

I Faktorertekek

Forrás: Saját számítás. 
A legfontosabb várostípusok a regionális központok, a részleges regionális központok, a megyeszékhelyek és térségi központok (középfokú centrumok), az aktív, dinamikus városok (azon belül is az uidülővárosok csoportja), a leszakadó városok, illetve az egyik csoporthoz sem tartozó mozdulatlan kis- és középvárosok csoportja. Budaörs, különösen az IKT szektorra koncentráló indikátorok esetében valamennyi csoporttól távol áll, ỏnállóan alkot egy típust.

\section{A klaszteranalizis alapján meghatározható infokommunikációs várostípusok}

A városok tipizálásához, a különböző városcsoportok meghatározása érdekében a kapott hat faktor értékéire többször lefuttattuk a $K$-mean dinamikus klaszteranalízist, különbözö paraméterek (klaszterek száma, klaszter középpontok) mellett. A faktoranalízist természetesen csak az IKT mutatók esetében is elvégeztük, ennek eredményeiről, mivel azok nagyon hasonlóak csak rövidebben számolunk be a késöbbiekben. A kapott eredményeket pedig diszkriminancia analízissel ellenöriztïk, ami lehetöséget adott néhány város esetében a csoportváltásra, hogy még pontosabb eredményeket kapjunk. A futtatások eredményeként összesen hat, egymástól jól megkülönböztethetö várostípust találtunk a magyar városhálózaton belül. Ezek a várostípusok egyfelöl bizonyos hierarchiát követnek, amit elsösorban a városok méretéböl fakadó keresleti tényezök határoznak meg, másfelöl azonban kimutatható egy, az IKT területén megmutatkozó aktivitásban, erőforrás mobilizálásban tetten érhetô különbség is a hasonló méretủ és funkciójú városok között. A hat várostípus a következö:

- Regionális központok

- Megyeszékhelyek és térségi központok

- Aktív kis- és középvárosok

- Üdülövárosok

- Mozdulatlan városok

- Leszakadó városok

A kizárólag az IKT mutatókra (12 változó) elvégzett elemzés során kialakult csoportok igen hasonlóak a komplex mutatórendszer alapján kapott eredményekhez. A fö különbség mindössze az, hogy a megyeszékhelyek és térségi központok csoportról leszakadtak a részleges regionális központi funkciókkal rendelkezö városok, és az üdülővárosok már nem különültek teljesen el (többségük az innovatív, aktív kisés középvárosok csoportjába került). Különösen magas faktorértékeinek köszönhetöen Budaörs pedig önállóan alkot egy csoportot (Budaörs már a komplex mutatórendszer szerint is viszonylag távol ált a többi csoporttól). A komplex és az IKT mutatórendszerhez kapcsolható infokommunikációs várostípusokat a 2-3. ábra mutatja. 

Tér és Társadalom, 17. 2003. 3. 145-163. p.

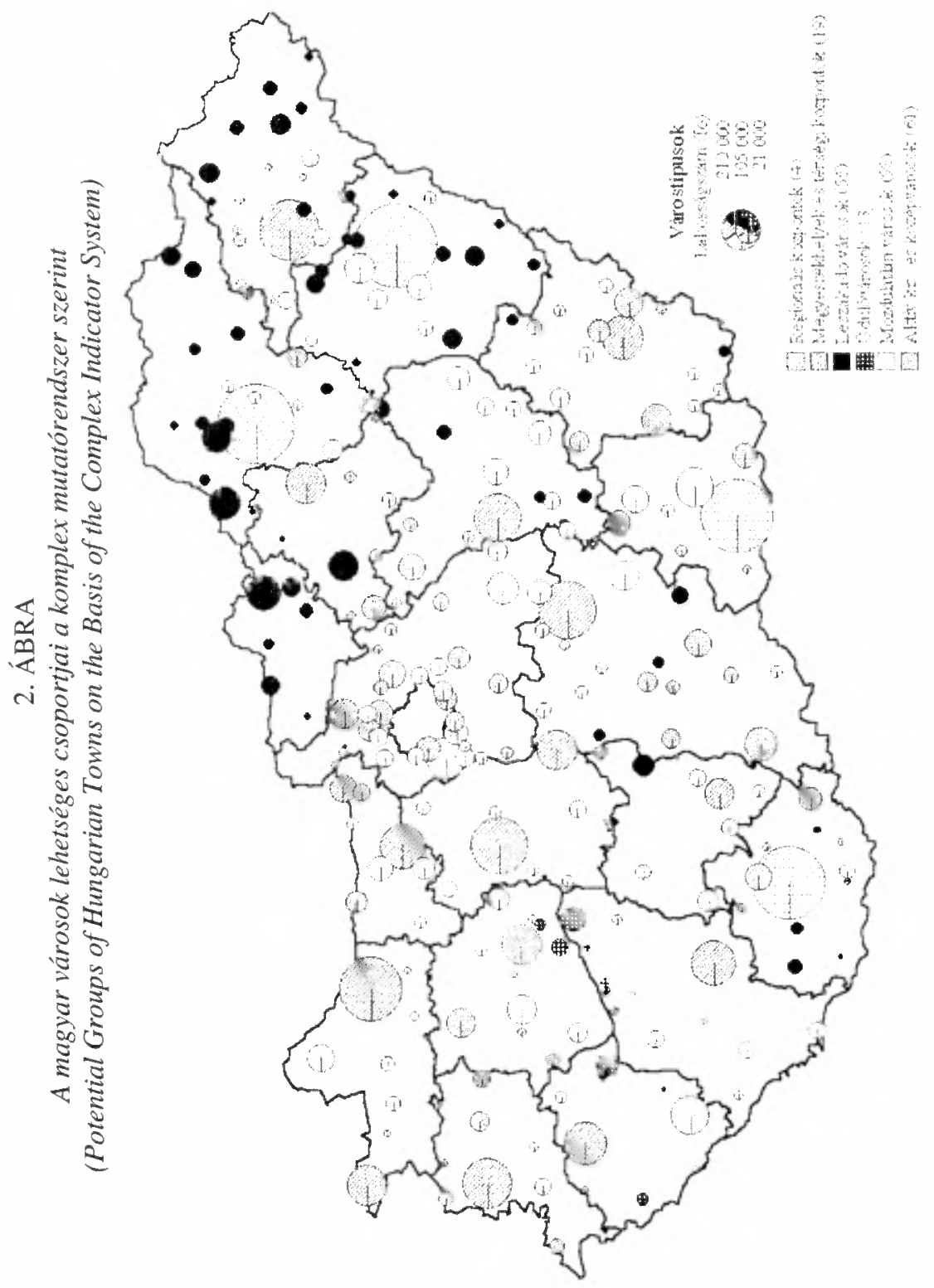



Tér és Társadalom, 17. 2003. 3. 145-163. p.

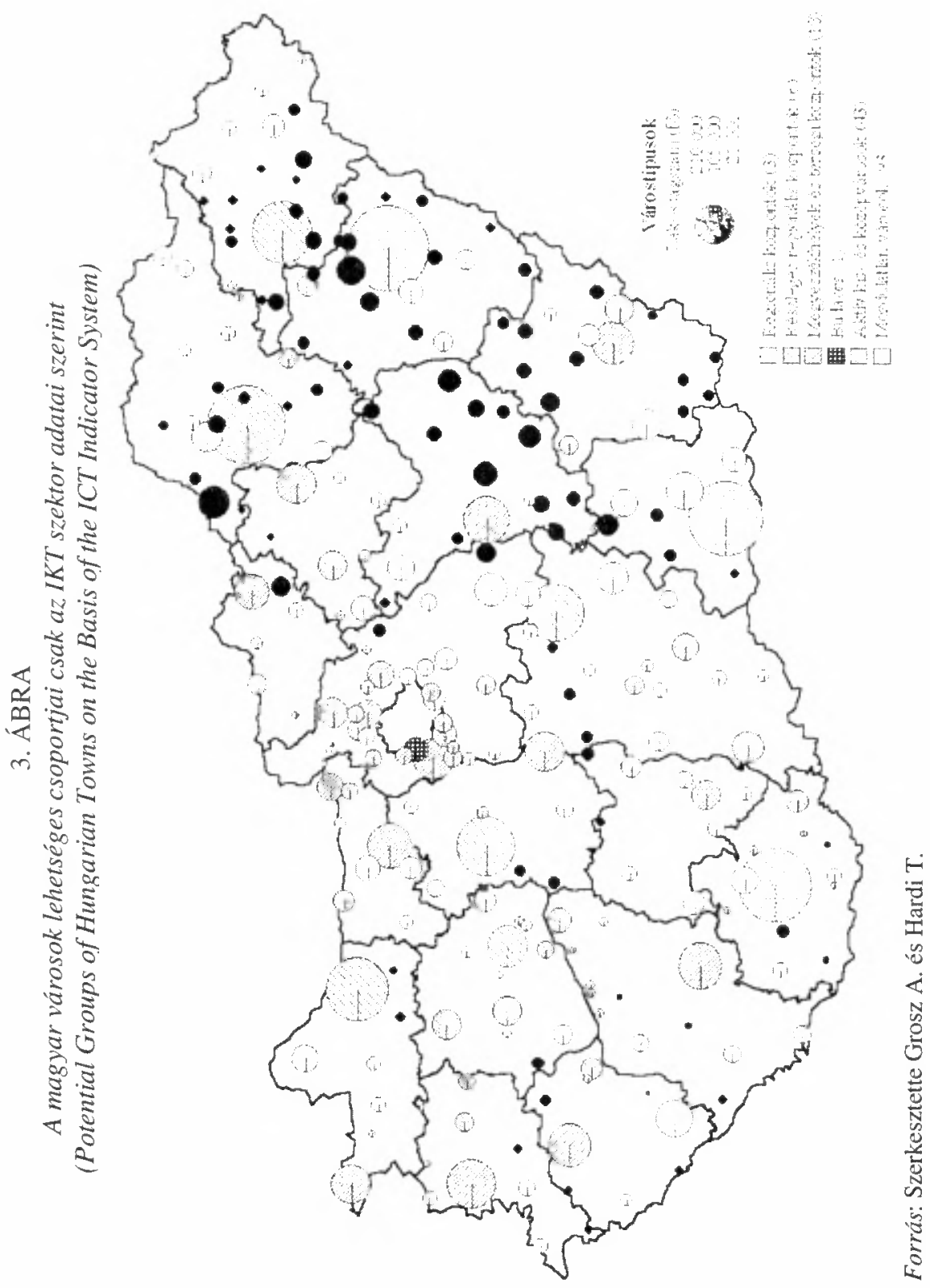


A városcsoportok mind a hozzájuk tartozó városok számát, mind az általuk reprezentált lakónépességet tekintve eltérö nagyságúak (3. táblázat). Míg a regionális központok típusba csak négy, azaz az összes város 1,5\%-a tartozik, addig itt él a városi lakónépesség közel 15\%-a, valamivel több, mint 700 ezer fö. Még nagyobb a megyeszékhelyek és térségi központok súlya, ahol már közel 1,3 millió magyar lakik, pedig e csoportot is mindössze 19 település alkotja. A dinamikus kis- és középvárosok köre már jóval szélesebb, összesen 74 város sorolható ide. Az 1 millió városlakót magáénak tudó klaszteren belül azonban különválik egy kisebb, az üduilővárosokat tartalmazó alcsoport 13 településsel. A legnagyobb halmazt az infokommunikációs szempontból mozdulatlannak tekinthető városok alkotják. Összesen közel 100 város nyújt otthont mintegy további 1,3 millió fö számára. A kisvárosok mellett e csoportban nagyobb települések is megtalálhatók. Végül szintén nagy elemszámú (56 város) az elmaradott, leszakadó városok köre. A leszakadás veszélye, az infokommunikációs technológiáknak köszönhető fejlödésből való kimaradás - idevéve a mozdulatlan városokat is - közel 2 millió városban élöt fenyeget hazánkban. Ezek az arányok nagyjából az IKT mutatórendszer esetében is megmaradtak, bár a leszakadó városok száma és az általuk képviselt lakosság aránya kissé emelkedett (3. táblázat).

\section{TÁBLÁZAT}

A különbözö várostípusok nagysága a két számitás eredményeként (The Size of Various Urban Types on the Basis of the Results from the Two Calculations)

\begin{tabular}{|c|c|c|c|c|c|c|c|c|}
\hline \multirow{3}{*}{ Városcsoportok megnevezése } & \multicolumn{4}{|c|}{$\begin{array}{l}\text { Komplex mutatórendszer } \\
\text { (32) }\end{array}$} & \multicolumn{4}{|c|}{ IKT mutatórendszer (12) } \\
\hline & \multicolumn{2}{|c|}{ Városok } & \multicolumn{2}{|c|}{ Népesség } & \multicolumn{2}{|c|}{ Városok } & \multicolumn{2}{|c|}{ Népesség } \\
\hline & $\mathrm{db}$ & $\%$ & fö & $\%$ & $\mathrm{db}$ & $\%$ & fö & $\%$ \\
\hline Regionális központok & 4 & 1,6 & 718 & 14,6 & 3 & 1,2 & 534 & 10,8 \\
\hline Részleges regionális központok & - & - & - & - & 6 & 2,4 & 705 & 14,3 \\
\hline Megyeszékhelyek, térségi & 19 & 7,6 & 1263 & 25,6 & 18 & 7,2 & 894 & 18,1 \\
\hline központok & & & & & & & & \\
\hline Aktív kis-és középvárosok & 61 & 24,3 & 906 & 18,4 & 43 & 17,1 & 631 & 12,8 \\
\hline Budaörs & - & - & - & - & 1 & 0,4 & 23 & 0,5 \\
\hline Üdülövárosok & 13 & 5,2 & 106 & 2,2 & - & - & - & - \\
\hline Mozdulatlan városok & 98 & 39,0 & 1284 & 26,1 & 93 & 37,1 & 1353 & 27,5 \\
\hline Leszakadó városok & 56 & 22,3 & 651 & 13,2 & 87 & 34,7 & 789 & 16,0 \\
\hline Összes város (Budapest nélkül) & 251 & 100,0 & 4.928 & 100,0 & 251 & 100,0 & 4928 & 100,0 \\
\hline
\end{tabular}

Forrás: Csizmadia Z. és Grosz A. számítása.

Alaphipotézisünket, miszerint a rendszerváltást követően várossá nyilvánított városok - hasonlóan a települések általános fejlettségében, az ellátandó központi, vagy térségszervezö funkcióinak számában, minöségében elért viszonylag kedvezőtlen eredményekhez - az infokommunikációs technológia szempontjából is egyértelmüen a leszakadó, valamint a mozdulatlan várostípusba sorolt települések listáját fogják gyarapítani, nem sikerült bizonyítani. A települések várossá nyilvánításának időpontja és a klaszterekbe sorolása között nem tapasztalható semmilyen szignifikáns korreláció, azaz a települések infokommunikációs várostípusa független a 

Tér és Társadalom, 17. 2003. 3. 145-163. p.

várossá nyilvánítástól. Egyedül az első két klaszter kivétel ez alól, ami teljesen természetes, hiszen egy település térségi, vagy föleg regionális központtá válása hosszú fejlödés eredménye, ami semmiképpen nem várható el egy néhány éves várostól. Az új városok előfordulási esélye a többi típusban szinte teljesen kiegyensúlyozott, mindazonáltal jelentös területi különbségek tapasztalhatók.

Az 1990 után várossá vált települések egyötöde $(20 \mathrm{db})$ az elmaradott, leszakadó csoportba került. Ezek fele az Észak-Alföldön található, a többi pedig ÉszakMagyarországon, vagy a Dél-dunántúli és a Dél-alföldi régióban. E térségekben csak elvétve találni néhány dinamikus kis- és középvárost (Pécsvárad, Lőrinci, Újszász, Jászárokszállás, Vésztö, Lajosmizse és Kecel). A városok fele mozdulatlannak tekinthetô, és ugyancsak egyötödük a dinamikus kisváros kategóriájába tartozik. Igaz a képet árnyalja, hogy ez utóbbiak nagy része a fövárosi agglomerációhoz tartozó, vagy ahhoz közel fekvő település (pl. Aszód, Gyál, Veresegyház, Dunaharaszti, Vecsés, Tököl). Az ország fejlettebb térségeiből egyetlen újonnan városi rangot nyert település sem számít elmaradottnak. A Budapest környéki és a közép-dunántúli városok fele-fele arányban a mozdulatlan, illetve a dinamikusan fejlödő csoportba kerültek, azonban a Nyugat-dunántúli régióban már nem volt ennyire kedvezö a kép. Több mint 62\%-uk a mozdulatlan városok számát gyarapította és csak Répcelakra mondható el, hogy lépést tart a fejlödési tendenciákkal. Ezzel szemben az Észak-magyarországi régióban az új városok több mint fele a hátrányos helyzetü, fejlödésben leszakadó várostípushoz tartozik, ezek közül csak a kedvezö elhelyezkedésü Emőd, Felsőzsolca és Lőrinci kivétel.

\section{A regionális központok csoportja}

Az első városcsoportba Miskolc, Szeged, Pécs, Debrecen, a már többször említett négy regionális központi funkciókkal rendelkezỏ nagyváros került. Ez a négy központ infokommunikációs szempontból is minden tekintetben kiemelkedik a településszerkezet többi tagja közül. A nagyvárosok átlagos lakosságszáma közel 180 ezer fö összesen mintegy 720 ezer ember él e centrumokban, - azonban valamennyire az erös elvándorlás jellemző, ami már egyértelmüen a szuburbanizációs tendenciáknak tudható be (még Pécsett is majd 18\%-kal meghaladja az elvándorlók száma az odavándorlókét, de Szegeden ugyanez az érték 39\%). Figyelmet érdemel, hogy az elmúlt 10 év gazdasági-társadalmi átalakulása nyerteseként aposztrofált ÉszakDunántúlon nem található olyan teljes értékü regionális központ, mint az ország többi térségében funkcionáló hagyományos egyetemi centrumok. Regionális központi szerepüknél fogva természetesen igen jelentős e centrumokban a gazdaság koncentrálódása. Az infokommunikációs szektorban szinte minden mutató tekintetében kiemelkednek a többi város közül. Különösen igaz ez az informatikusképzésre (a középfokúra is, de egyetemi központként föleg a felsőfokúra). Az IKT szektorhoz kapcsolódó vállalkozások koncentrációja a regionális központokban sokkal jelentősebb, mint az összes gazdasági szervezeté, ami azt mutatja, hogy ebben a szektorban még mindig nagyon fontos a központi funkciókkal bíró településekhez való 
közelség. Az ágazaton belül a legszembetúnőbb a termékhez kapcsolódó, illetve a termékhez nem kapcsolható IKT szolgáltatások jelenléte. Bár az internetszolgáltatók számát tekintve már több csoport is felzárkózott a regionális központokhoz, e városokban még mindig többféle internetes szolgáltatási forma közül választhatnak a potenciális ügyfelek, mint a többi vidéki városban. A ma már hagyományosnak tekinthetö kommunikációs technológiák terén egyáltalán nem nevezhető kiemelkedőnek e négy nagyváros pozíciója. A telefonellátottságban, az üzleti szféra vezetékes telefonellátottságában, de még a mobil előfizetők számát tekintve sem tapasztalható különbség a következö csoportot alkotó középszintủ központokkal összehasonlítva. A városokban bejegyzett domain szerverek száma 1000-1500 körüli, egyedül Miskolc maradt le e téren a maga 550 körüli szerver számával. A regionális központok infokommunikációs szektorban betöltött szerepére hívja fel a figyelmet, hogy kizárólag az IKT szektorra vonatkozó mutatókat tartalmazó elemzésben a legfontosabb központként e négy város közül három került meghatározásra (Debrecen, Szeged, Pécs).

A megyeszékhelyek és térségi központok csoportja

A második városcsoportba összesen 19 város került. A 19 város közül 12 megyeszékhely, további kettő pedig megye jogú város (Sopron, Dunaújváros), ezért nyugodt szívvel nevezhetjük e csoportot a megyeszékhelyeket és a térségi központokat magában foglaló várostípusnak. A megmaradt négy klasztertag speciális helyzetben lévö, Budapest agglomerációjához tartozó dinamikusan fejlődő középváros (Budaörs, Esztergom, Szentendre, Vác). A négy város méretéhez képest elökelöbb infokommunikációs pozíciója és eredménye mindenképpen az igen erös föváros felé mutató kapcsolatoknak köszönhetö. A városok elhelyezkedése még viszonylag kiegyensúlyozott, azonban már enyhén elötérbe kerül az észak-dunántúli térség. Az előzỏ négy várost is figyelembe véve megállapítható, hogy mindössze egyetlen olyan megye van (az egyébként általános fejlettségét tekintve utolsó helyen szereplő Nógrád), amelyben nincs egyetlen egy felsö- vagy középfokú központ, míg három megyében (Györ-Moson-Sopron, Fejér és Komárom-Esztergom) kettő, Pest megyében pedig három ilyen centrum is található. A csoport középpontjától a legtávolabb Budaörs esik, e város alaposabb megismerése speciális helyzete és funkciója miatt mindenképpen indokolt. Budaörs egyébként a csak IKT változókon alapuló vizsgálat során önállóan alkot egy csoportot (3. ábra). A térségi központoknak tekinthetö településeken összesen mintegy 1,3 millió ember él, így a városban élő lakosság valamivel több, mint egynegyede e csoporthoz tartozik. Kisebb mértékben, de ugyancsak távolabb van a csoport gravitációs középpontjától már az elözỏ csoportnál is említett négy részleges regionális központ.

A klaszter legtipikusabb települései a 70-80 ezer fös Kaposvár, Szolnok és Tatabánya. A csoportra szintén jellemzö az enyhe elvándorlás, de már nem olyan mértékben, mint a regionális központok esetében. Az idetartozó települések a regionális központok után az infokommunikációs szektor tekintetében mindenképpen vezető pozíciót töltenek be a hazai településszerkezetben. Egyfelöl a hierarchikus telepü- 
lésrendszerben ez az a második szint, ahol megfigyelhetö az IKT szektorhoz kapcsolódó képzés egyértelmü koncentrációs folyamata, ami néhány felsőfokú intézmény mellett elsösorban a középfokú informatikai, számítástechnikai képzést jelenti. A képzés mellett a legmodernebb infokommunikációs technológiák, ágazatok tekintetében is intenzív gazdasági tevékenység jellemzi öket. Mind a feldolgozóipari IKT cégek, mind az IKT szolgáltató vállalkozások sürüsége jóval meghaladja az összes müködö vállalkozás koncentrációjának mértékét. Persze ehhez jelentősen hozzájárul a rendelkezésre álló infrastruktúra és szolgáltatási háttér (internetes szolgáltatási formák, bejegyzett domain szerverek száma), mely ugyancsak kedvezöbb, mint a többi csoportba tartozó városok esetében. A megyeszékhelyek és térségi központok csoportjába tartozó - amennyiben csak a 12 közvetlen IKT mutatót vesszük figyelembe részleges regionális központnak is tekinthetö - Györ legfontosabb infokommunikációs sajátosságait vizsgálja Barsi és Csizmadia (Barsi-Csizmadia 2001).

Az aktív kis- és középvárosok csoportja

A 3. klaszter az aktív, az átlagosnál viszonylag fejlettebb infokommunikációs infrastruktúrával és müködö IKT ágazattal rendelkezö kis- és középvárosok csoportja. Összesen 61 település tartozik ide, átlagos lakónépességük 15 ezer fö körüli, így a klaszter valamivel több, mint 900 ezer föt foglal magában. A városok földrajzi elhelyezkedésüket tekintve két nagyobb csoportba oszthatók. Többségük a fóváros 60-70 km-es vonzáskörzetében található, különösen az agglomerációs gyürüben (pl. Dunakeszi, Gyál, Törökszentmiklós, Vecsés stb.), míg a másik nagyobb csoport a dél-alföldi régióban koncentrálódik (pl. Baja, Kiskörös, Kiskunhalas, Makó, Orosháza stb.). E két szükebb térségen kívül még a Dunántúl északi részén fordul elö nagyobb arányban (Komárom, Dorog, Várpalota, Pápa, Sárvár stb.), míg az ország többi régiójában már jóval ritkábban található dinamikus kisváros (pl. Komló, Tiszaújváros, Tokaj stb.). A csoporthoz való tartozás egyik domináns faktora a vándorlási különbözet. Az összes klaszter közül e csoportban tapasztalható egyedül a népességfelszívó erö. A településeken átlagosan $15 \%$-kal haladja meg az odavándorlók száma az elvándorlókét. A vándorlás legfontosabb tényezőjeként mindenekelött a dinamikusan fejlödö gazdaság ismerhető fel. Ezen városokban mind a jövedelmi mutatók, mind az IKT szektorhoz kapcsolódó mutatók értékei (különösen az IKT termékhez kapcsolódó szolgáltatók és a médiagazdaság vállalkozásai) meghaladják az ezt követő csoportok átlagait. A mozdulatlan városokénál jelentős mértékben, több mint 30\%-kal magasabb a mobil elófizetések száma is, míg a bejegyzett domain szerverek száma és az elérhetö internetes szolgáltatások tekintetében már majd kétszeres ez a különbség.

\section{Az üdülővárosok csoportja}

A 4. klaszternek összesen mindössze 13 tagja van, és kisvárosok lévén - átlagos lakosságuk alig éri el a 8 ezer föt - mindössze 100 ezer fö otthonát jelentik. Mindazonáltal az összes közül az egyik legkarakteresebb, leginkább homogén városcso- 
portnak nevezhetö. Az elsősorban Balaton parti települések (Balatonfüred, Balatonboglár, Balatonlelle, Fonyód, Keszthely, Balatonalmádi, Siófok Balatonföldvár) mellett idetartoznak a termálturizmus további kiemelkedó centrumai is (pl. Harkány, Hévíz, Zalakaros). A csoporthoz való tartozást egyértelmủen a gazdasági aktivitás faktora határozza meg, de nagymértékben befolyásolja a vándorlások aránya is. Az üdülővárosok egyértelmüen kisvárosok, azonban fejlödésüket jelzi, hogy az odavándorlások száma jelentősen (10\%-kal) meghaladja az elvándorlásokét. A vándorlásokat természetesen az országos átlaghoz viszonyított kedvezö gazdasági környezet és lehetöségek indukálják. A gazdasági aktivitás ezekben a városokban kiemelkedő: az 1000 lakosra jutó gazdasági szervezetek átlagos száma kétszerese a többi hasonló méretü kis- és középvárosban jellemzőknek. A müködö vállalkozások és az egyéni vállalkozások fajlagos mutatója - mindkettő csoportátlaga közel 90\%-kal haladja meg a 251 városra jellemzỏ átlagos értéket - különösen magas. A személygépkocsik száma - hasonlóan a vezetékes telefonellátottsághoz - ugyancsak a legmagasabb, valamennyi csoport közül $42 \%$-kal meghaladja a városi átlagot. Az üdülővárosok az IKT szektorhoz kapcsolódó mutatók tekintetében (IKT vállalkozások, oktatás, informatikai képzés) már nem térnek el jelentösen a hasonló méretủ városoktól. $\mathrm{Az}$ infokommunikációs szektorhoz köthetỏ cégek számát tekintve a csoport a mozdulatlan kis- és középvárosokhoz hasonlít leginkább (5. klaszter). Az informatikai képzés és az internetes szolgáltatások elérhetösége, valamint a domain szerverek száma is teljesen átlagos.

\section{A mozdulatlan városok csoportja}

Az 5. klaszterbe az a közel 100, elsősorban kis- és középváros tartozik, amelyek az infokommunikációs szektor fejlődését tekintve a városhálózatban mozdulatlannak mondhatók. A klaszter nem csak elemszámát, de az általa érintett lakosság nagyságát tekintve is a legjelentösebbnek mondható, amely majdnem eléri az 1,3 millió föt. Tipikusan kis- és középes méretü városok alkotják (átlagosan 13 ezer fö), azonban néhány nagyobb település is e csoportba került (Nagykanizsa, Hódmezővásárhely, Érd). Ezek a városok földrajzilag már nem mutatnak olyan egységes képet, mint az előzőek, az ország valamennyi régiójában található mozdulatlan város. Érdekes, hogy általában a társadalmi-gazdasági szempontok alapján legfejlettebb Györ-Moson-Sopron, illetve Fejér megyében - az IKT szektort a vizsgálat középpontjába állítva - nagy különbségek tapasztalhatók. Mindkét megyében csak a két-két megye jogú város emelhetö ki, míg az összes többi a mozdulatlan városok kategóriájában található. A mozdulatlan, átlagos fejlettségü városok ugyanakkor megtalálhatóak a Dél-Dunántúlon (pl. Barcs, Dombóvár, Siklós, Tolna stb.), valamint a Budapestet körülölelő agglomerációban is (Budakeszi, Pomáz, Pilisvörösvár, Törökszentmiklós stb.). Jelentős koncentrációt mutat az ország keleti felén, különösen az észak-alföldi városok körében. E csoport tagjai föleg az elmúlt évtizedben várossá nyilvánított települések köréböl kerülnek ki (pl. Demecser, Rakamaz, Létavértes, Baktalórántháza, Tiszaföldvár, Máriapócs, Polgár, Jászfényszaru, 
Ibrány, Tiszalök, Újfehértó). A csoport legtipikusabb városai Lengyeltóti, Kisbér, Oroszlány, Nagykőrös, Sásd, Tamási, Mindszent. A csoporttagok mozdulatlanságát mutatja, hogy az odavándorlások és az elvándorlások között alig fedezhetỏ fel különbség. A munkanélküliségi ráta ezekben a városokban az országos átlag közelében mozog $(6,5 \%)$. A gazdasági szervezetek számához képest alacsonynak mondható az IKT ágazatban érdekelt vállalkozások aránya. A mozdulatlan városok infokommunikációs sajátosságai részletesebb bemutatása további problémákra hívja fel a figyelmet Zirc város kapcsán (Barsi 2002).

\section{A leszakadó városok csoportja}

A hatodik csoportot az infokommunikációs szempontból legkevésbé fejlett, legelmaradottabb városok alkotják, összesen 55 , a hazai városok több mint egyötöde (22\%) tartozik e települestípusba. A jellemzően északkelet-magyarországi kis-és középvárosok között - a csoportba tartózó városok átlagos állandó lakossága nem éri el a 12 ezer fỏ́t-, megtalálható néhány nagyobb város (pl. Ózd, Kazincbarcika), sőt egy megyeszékhely (Salgótarján) is, igaz a klaszter középponttól mért távolsága viszonylag nagynak mondható. A klaszterhez tartozó városokban valamivel több mint 650 ezer fö él. A csoport az összes közül földrajzi értelemben a leginkább koncentrált. Nógrád megyéböl valamennyi város, a Borsod-Abaúj-Zemplén megyében található 20-ból 13, a Hajdú-Bihar megyei 19-böl 12, és Szabolcs-SzatmárBereg megyéböl is nyolc város e típusnak a tagja. Az északkelet-magyarországi városok mellett tagja néhány dél-alföldi és dél-dunántúli, fỏleg Baranya megyei település is (pl. Bóly, Sellye, Szigetvár, Szentlörinc). A klaszter középponthoz legközelebb eső, tịpikusnak mondható telepủlések Bátonyterenye, Simontornya, Kiskunmajsa, Sátoraljaújehely, Sárospatak, Borsodnádasd. Az elmaradottsággal járó problémákat és a jövőbe vetett bizalmatlanságot, bizonytalanságot mutatja, hogy a csoportba tartozó telepulésekröl elvándorlók száma körülbelül 10\%-kal meghaladja az odavándorlókét. Az IKT szektor fejletlenségét elsősorban az átlagos fejlettségi szint, az általános jövedelmi szint rendkívül alacsony értékével lehet magyarázni. Messze a legalacsonyabb az 1000 lakosra jutó személygépkocsik száma (20\%-kal marad el az országos átlagtól), az épített négyszobás vagy annál nagyobb lakások száma pedig a 251 városra jellemzó átlag negyedét sem éri el. A fejletlen, elmaradott csoport városaiban a gazdasági szervezetek száma, a múködő vállalkozások, az egyéni vállalkozások fajlagos mutatói egyértelmủen a legalacsonyabb értéket mutatják, aminek következtében az IKT szektorhoz kapcsolódó vállalkozások is a sereghajtók közé tartoznak. Ugyanez igaz a fejlödéshez szükséges alapvető, valamint infokommunikációs infrastruktúrára is. Nemcsak a bejegyzett domain szerverek és az internetszolgáltatók száma a legalacsonyabb, de a vezetékes és a mobil telefonellátottság is elmarad a többi városétól. Ezt követően nem csodálkozhatunk azon, hogy mind a munkanélküliségi ráta, mind a tartósan munkanélkuliek aránya legalább kétszerese bármelyik másik várostípusra jellemző értéknek. 


\section{Az IKT mutatórendszer alapján megfogalmazható sajátosságok}

Mint már említettük a kizárólag csak IKT mutatókon alapuló vizsgálattal összesen hét városcsoport ismerhető fel. Ezek az IKT várostípusok nagymértékben hasonlítanak a komplex mutatórendszer által bemutatott csoportokra. A fö fejlödési tendenciák teljes mértékben felismerhetők, csak kisebb eltérések figyelhetök meg a két vizsgálat között, ezért most csak ezeket az eltéréseket szeretnénk röviden bemutatni.

A városhálózatból az eddigi vizsgálatokhoz hasonlóan egyértelmúen kiemelkednek a regionális központi funkciókkal rendelkezö városok. Ez jelen esetben kilenc várost jelent (pluszként Veszprém csatlakozott a csoporthoz, valószínüleg elsösorban müszaki egyetemi hátterének köszönhetően). A csoporton belül is két klaszter található: Debrecen, Pécs és Szeged, mint hagyományos egyetemi központok sokkal nagyobb aktivitást mutatnak az infokommunikációs ágazatban, mint a többi regionális központ. A regionális, vagy felsőfokú központok egyértelmủen a felsőoktatásban betöltött funkciójuknak, illetve a vállalkozások számára viszonylag nagy piac elérhetöségét jelentő városméretnek köszönhetik előkelö pozíciójukat.

Kiemelkedik a regionális központokat követő hierarchikus szint, melyet 18 város alkot. Ezek a városok egyrészt a megyei jogú városok, melyek térségi központi funkciójuknál fogva az IKT terén is kiemelkednek a többi közül, másrészt pedig a Budapest vonzáskörzetében, illetve agglomerációjában található közepes méretü városok (Dunakeszi, Vác, Budakeszi, Esztergom és Érd). Hasonlóan a budapesti agglomerációhoz tartozó Budaörs önállóan alkot egy csoportot. Az infokommunikációs szektorban egyetlen másik várostípushoz sem lehet besorolni ${ }^{8}$.

Amennyiben csak az IKT mutatókat vesszük figyelembe, jóval szükebb azon városok köre - nem ideszámítva a felsőfokú és a középfokú, térségi funkciókat ellátó városokat -, ahol az IKT szektorhoz kapcsolódó infrastruktúra kiépítettségét, valamint az ágazatban müködő vállalkozások gazdasági aktivitását tekintve kifejezetten pozitív folyamatoknak lehetünk tanúi. Az országban mindössze 43 város tartozik ebbe a körbe. Elhelyezkedésüket tekintve az IKT adaptálására elsösorban Budapest környéki kisvárosok és az Észak-Dunántúlon található kis- és középvárosok képesek. Az ország többi részén csak elvétve találunk ilyen aktív városokat.

A legnépesebb klaszter az infokommunikációs jellemzőket tekintve a mozdulatlan, különösebb fejlődési dinamikát felmutatni nem képes, azonban nem is a leszakadó, vagy elmaradott városok csoportja. A 93 hazai város területi elhelyezkedését tekintve semmilyen fóldrajzi koncentráció nem figyelhetö meg. Az ország legfejlettebb és legkevésbé fejlett régióiban, térségeiben egyaránt megtalálhatók. Föleg kisés középvárosok tartoznak e típusba, azonban ide került a megyei jogú városok közül Nagykanizsa és Hódmezővásárhely is.

Viszonylag nagy számú az elmaradottnak tekinthetö, az infokommunikációs tevékenységhez kapcsolódó folyamatokban egyre inkább leszakadó városok típusa, amelybe összesen 86 város került. Föleg az ország keleti felén koncentrálódnak (különösen Jász-Nagykun-Szolnok, Hajdú-Bihar, Szabolcs-Szatmár-Bereg, Békés és Borsod-Abaúj-Zemplén megye), de megtalálhatók az átlagos fejlettségi szintet 
tekintve a hátrányos dunántúli területek is, mint belső Somogy, Baranya, vagy VasZala-Veszprém megyék határa. A föváros kisugárzó hatását mutatja, hogy tágabb térségében nem található e csoportba tartozó văros.

\section{Összefoglaló megállapítások}

Végül szeretnénk néhány gondolatban összegezni a várostipizálás legfontosabb tapasztalatait. Ezek szerint a városok infokommunikációs technológiai fejlettségének, az elérhető infrastruktúra és az IKT szolgáltatások felmérésének eredményeként számos különbözö csoport fedezhető fel. Ezek kialakulásában számos tényező játszik szerepet, azonban mindenképpen megfigyelhető néhány különösen fontos sajátosság.

Az egyik legfontosabb tényezö, amely a települések infokommunikációs fejlettségét befolyásolja, a városok mérete, valamint az azzal ok-okozati viszonyban lévő, a történelmi fejlődés során elért központi funkciója, szerepe. Az ország hagyományos centrum települései - megyeszékhelyek, megyei jogú városok, regionális központok -, melyek hosszú évtizedek óta a társadalmi-gazdasági fejlődés legfontosabb gócpontjai, az infokommunikációs technológia fejlettségének szemszögéből is kiemelkednek az ország térszerkezetéből.

E városokban koncentrálódik az IKT szektorhoz kapcsolódó vállalkozások nagy része (feldolgozóipari és szolgáltató cégek egyaránt), a rendelkezésre álló kommunikációs infrastruktúra (mind a hagyományos, mind a legmodernebb internet-alapú) és az ahhoz kapcsolódó szolgáltatások jóval meghaladják a kis- és közepes méretü városokban elérhetőket, de jelentỏs az előnyük az informatikai képzés területén is. Közülük is külön csoportot alkotnak a tradicionális regionális központok (Debrecen, Szeged, Pécs és talán Miskolc), melyek különleges pozícióját erősíti egyetemi funkciójuk is.

E négy centrumhoz képest lemaradva, de a megyeszékhelyektől, térségi központoktól némileg mégis elkülönülve körvonalazódik a részleges regionális központok klasztere. Az IKT mutatók alapján Györ, Kecskemét, Székesfehérvár és Nyíregyháza mellett elsősorban egyetemi hagyományainak köszönhetöen - ide sorolható Veszprém is.

A megyeszékhelyek és a térségi központi funkciókkal rendelkező városok alapvetően két csoportra oszthatók. Egyfelöl a következö hierarchikus szinten található megyeszékhelyek és megyei jogú városok alkotják e klasztert, melyek a településszerkezetben hagyományosan kiemelkedő szerepet játszottak és játszanak, másfelől pedig néhány Budapest környéki közepes méretủ város csatlakozott e csoporthoz. Vác, Szentendre, Budaörs, Gödöllő, Budakeszi, Dunakeszi, Érd és Esztergom egyértelmüen a főváros közelségének, az elmúlt évtizedben felerősödő szuburbanizációs tendenciáknak és többek között az infokommunikációs szektor szétterjedésének köszönheti dinamikus fejlődését.

Főleg a budapesti agglomerációban, az általános társadalmi-gazdasági fejlettségét tekintve fejlettebbnek tekinthető Észak-Dunántúlon, valamint a dél-alföldi régióban számos aktívnak mondható, dinamikusan fejlödő kis- és középváros található. 
Ezekben mind az infokommunikációs infrastruktúra kiépítettsége, mind az IKT vállalkozások tevékenysége meghaladja az országos átlagot.

Aktivitásukat és mobilitásukat tekintve homogén várostípust alkotnak az ún. üdülö, vagy fürdővárosok is, azonban ezek specializációjuk miatt infokommunikációs szempontból már nem tekinthetők különösen kiemelkedőnek. A legtöbb kis- és közepes méretű város - mintegy 100 - nem mutat jelentősebb aktivitást e területen, sokkal inkább a stagnálás figyelhető meg esetükben. Végül igen jelentös számú $(58 \mathrm{db})$ telepủlés került a fejlődésben elmaradott, leszakadó városok klaszterébe, amelyek kifejezetten az északkelet-magyarországi térségben koncentrálódnak (természetesen a többi régióban is található egy-egy).

Összességében megállapítható, hogy a magyar városhálózat infokommunikációs várostípusait elsősorban a városok mérete (a hagyományos nagyvárosok, megyeszékhelyek és a kis- és középvárosok közötti különbségek), földrajzi elhelyezkedése (dinamikusan fejlődö-mozdulatlan, stagnáló-elmaradott, leszakadó térségek egyenlötlenségei), valamint egyéb speciális jellemzỏi (pl. üdülővárosi funkciók dominanciája, fővárosi agglomerációhoz való tartozás, egyetemi és felsőoktatási kỏzpontok) határozzák meg. Alaphipotézisünkkel ellentétben azonban nem mutatható ki szoros kapcsolat a várossá nyilvánítás időpontja és az infokommunikációs fejlettség között. A regionális és térségi központokat nem számítva, az elmúlt évtized új városai között egyaránt megtalálható aktív, dinamikusan fejlödö, mozdulatlan, valamint leszakadó kisváros.

Elmondható, hogy a 251 hazai városból az infokommunikációs technológiák fejlettségét, a rendelkezésre álló infrastruktúrát és az elérhető szolgáltatásokat tekintve mindössze 20-25 tekinthető igazán fejlettnek, ami azonban a Budapesten kívüli városi lakosság körülbelül $40 \%$-át jelenti ( 2 millió fö). Emellett még mintegy 1 millióan élnek az előbbi csoporthoz felzárkózni próbálkozó, 70-75 viszonylag aktív kis- és közepes méretü városban, míg a többi, valamivel több mint 150 városban alig tapasztalható bármilyen pozitív folyamat. Sőt, közülük mintegy 60 kifejezetten elmaradottnak és a fejlődésben leszakadónak számít. Az infokommunikációs szektor fejlődéséből ez által jórészt tulajdonképpen kimaradó városi lakosság száma így ugyancsak megközelíti a 2 millió fót.

Infokommunikációs szempontból az ország térszerkezete, településszerkezete kisebb-nagyobb mértékben tagolt, egyensúlytalanságok tapasztalhatók. A legfejlettebbnek tekinthetö - regionális és térségi központok - városok többsége az ÉszakDunántúlon, valamint a Budapestet körülvevő agglomerációs gyürủben található, míg az ország déli és keleti felén (Dél-Dunántúl és a Dunától keletre eső területek) kedvezötlenebb helyzetben van. Ezt erösíti a leszakadó városok elhelyezkedése is, melyek egyértelmüen Északkelet-Magyarországon koncentrálódnak. Infokommunikációs szempontból a leginkább elmaradottnak a Salgótarján-Szolnok-Békéscsaba vonaltól keletre fekvő térség tekinthető. 


\section{Jegyzetek}

${ }^{1}$ Azon középfokú intézmények kerültek számbavételre, amelyeken a 2001/2002-es tanévben informatikai, vagy számítástechnikai specializáció indult.

${ }^{2}$ Azon állami és magán felsöfokú intézmények (egyetemek és főiskolák) kerültek számbavételre, amelyeken a 2001/2002-es tanévben informatika, müszaki informatika, programozó matematikus, vagy számítástechnika szakot indítottak.

${ }^{3}$ A KSH 2001-ben megjelent kiadványa (Az információs és kommunikációs technológiai szektor... 2001) az infokommunikációs szektor vállalkozásait azok TEÁOR kódja alapján a következöképpen csoportosítja:

- IKT feldolgozóipari vállalkozások: 3001 Irodagépgyártás, 3002 Számítógépgyártás, 3130 Szigetelt vezeték és kábel gyártása, 3210 Elektronikus alkatrész gyártása, 3220 Ipari híradástechnikaj termékek gyártása, 2330 Híradástechnikai fogyasztási cikk gyártása, 3320 Mérőmüszer gyártása, 3330 Ipari folyamatirányító rendszer gyártása.

- Termékhez kapcsolódó IKT szolgáltatásokat nyújtó vállalkozások: 5143 Elektromos háztartási cikk nagykereskedelme, 5164 Irodagép, -berendezés nagykereskedelme, 5165 Egyéb gép, szállítóeszköz nagykereskedelme, 7133 Irodagép, számítógép kölcsönzése.

- Nem termékhez kapcsolódó IKT szolgáltatásokat nyújtó vállalkozások: 6420 Távközlés, 7210 Hardver-szaktanácsadás, 7220 Szoftverkészítés, -szaktanácsadás, 7230 Adatfeldolgozás, 7240 Adatbanki tevékenység, 7260 Számítástechnika tevékenység.

4 A médiagazdasághoz tartozó vállalkozások közé a nyomtatott, képi és hangi termékekkel kapcsolatos tevékenységek, a hirdetés- és reklámszolgáltatók, valamint a távközlés, posta, TV, rádió és a filmek területén tevékenykedö cégek kerültek számbavételre.

5 A mutatóban az internetes szolgáltatási formák mellett a következő távközlési szolgáltatási formák száma is szerepel: osztott uizleti hálózati szolgáltatás, internet-hozzáférés szolgáltatás, voip szolgáltatás, egyéb adathálózati szolgáltatás, integrált távközlési szolgáltatás, egyéb távközlési szolgáltatás, vezetékes müsorjel szolgáltatás, elektronikus üzenetkezelés és információszolgáltatás, televízió müsorszóró szolgáltatás, összekapcsolási szolgáltatás, távkonferencia szolgáltatás.

${ }^{6}$ MTA RKK ATI Számítóközpont gyűjtése az államigazgatás szervezeteire, a civil szervezetekre és pártokra, az oktatási és kutatóintézetekre, a vállalkozásokra és a magánszemélyek által regisztrált domainekre egyaránt kiterjedt.

7 A magyarországi mobilszolgáltatók közuil a Pannon GSM és a Vodafon rendelkezésünkre bocsátotta előfizetőinek számát, azonban a Westel elzárkózott az együttmüködéstől. A megkötött szerződések értelmében az elöfizetőkre vonatkozó adatokat csak az elemzéshez szabad felhasználni, az egyedi adatközléshez nem járultak hozzá.

${ }^{8}$ Budaörs speciális helyzetủ város a föváros közvetlen közelében. A város kiemelkedö ellátottsága az IKT szektorból magyarázza, hogy több országos jelentöségủ gazdasági egység központja telepult ide Budapestről (pl. mobil telefontársaság, kereskedelmi egységek, stb.), de lakossága is dinamikusan emelkedik, akik között többségben vannak a magasabb jövedelmủek, jól képzettek.

\section{Irodalom}

A magyar gazdaság a 2000. évben. (2001) Gazdasági Minisztérium, Budapest. (http://www.gm.hu/ fomenu/sajtoszoba/htm/kiadv/index.html, letöltve 2001. dec.)

Az információs és kommunikációs technológiai szektor Magyarországon 1995-1999. (2001) Központi Statisztikai Hivatal, Budapest.

Barsi B. (2002) Egy kisváros helyzete az információs társadalomban. - Tér és Társadalom 3. 85-102. o.

Barsi B.-Csizmadia Z. (2001) Egy nagyváros helyzete az információs társadalomban. - Tér és Társadalom. 2. 147-172. o.

Beluszky P. (1999) Magyarország településföldrajza. Dialóg Campus Kiadó, Budapest-Pécs.

Dỏry T.-Grosz A. (szerk.) (2002) Az információhoz való hozzájutás társadalmi és földrajzi különbségei Magyarország városhálózatában. NYUTI Közlemények 137. MTA RKK Nyugat-magyarországi Tudományos Intézet, Györ.

Grosz A.-Lados M. (szerk.) (2001) A gazdasági-társadalmi hatásvizsgálatok és értékelések. NYUTI Közlemények 133. MTA RKK Nyugat-magyarországi Tudományos Intézet, Győr. 
Grosz A.-Rechnitzer J. (szerk.) (2000) Fejlődési pályák a magyar városhálózatban. NYUTI Közlemények 110. MTA RKK Nyugat-magyarországi Tudományos Intézet, Győr.

Hirközlési Statisztikai évkönyv 1999. (2000) Hírközlési Főfelưgyelet Piaci Monitoring Igazgatóság, Budapest.

Lengyel I.-Rechnitzer J. (2000) A városok versenyképességérỏl. - Horváth Gy.-Rechnitzer J. (szerk.) Magyarország területi szerkezete és folyamatai az ezredfordulón. MTA Regionális Kutatások Központja, Pécs. 130-152. o.

Nagy G. (2002) Területi különbségek az információs korszak küszőbén. (Mit mérünk, és hogyan?) Teriuleti statisztika. 1. 3-25. o.

Nemes Nagy J. (1995) Soprontól Nyíradonyig. Városok a piacgazdasági átmenetben. - Comitatus. 8-9. 5-22. 0 .

Rechnitzer J. (1993) Szétszakadás vagy felzárkózás? Az innovációt alakító térszerkezet. MTA Regionális Kutatások Központja, Györ.

Rechnitzer J. (2002) A városhálózat az átmenetben, a kilencvenes évek változási irányai. - Tér és Társadalom. 3. 165-184. o. 